Buletin JSJ, 3 (2), 2021, 71-81

Available online di: http://ejournal-balitbang.kkp.go.id/index.php/JSJ/index

\title{
PENENTUAN UMUR SIMPAN ABON IKAN CAKALANG (Katsuwonus pelamis) DI UMKM MAHA KARYA, KABUPATEN PANGANDARAN
}

\section{DETERMINATION OF THE SHELF LIFE OF SHREDDED SKIPJACK TUNA (KatsuwonUS pelamis) AT MSME MAHA KARYA, PANGANDARAN}

\author{
Sujuliyani, Niken Dharmayanti, Nofi Sulistiyo Rini, Alfina Salma Lathifa \\ Teknologi Pengolahan Hasil Perikanan Politeknik Ahli Usaha Perikanan, \\ JI. AUP No. 1 Pasar Minggu-Jakarta Selatan; Telepon +21-7805030 Jakarta 12520 \\ *Email: nofi.sulistiyo@gmail.com
}

\begin{abstract}
ABSTRAK
Pesisir pantai Pangandaran Jawa Barat merupakan salah satu penghasil produk abon ikan cakalang dikarenakan tingginya potensi hasil tangkap ikan cakalang. Salah satu penghasil produk abon ikan cakalang di Pangandaran adalah di UMKM Maha Karya. Penelitian ini bertujuan untuk mengetahui karakteristik mutu, nilai gizi, dan daya awet produk dengan metode ASLT. Penentuan umur simpan abon menggunakan dua perlakuan kemasan alumunium foil dan paper kraft dengan tiga parameter suhu $\left(30^{\circ} \mathrm{C} 40^{\circ} \mathrm{C}\right.$, dan $\left.50^{\circ} \mathrm{C}\right)$. Mutu abon cakalang pada kemasan alumunium mempunyai karakteristik dengan memiliki kadar air $5.42 \%$, kadar abu $5.93 \%$, kadar protein $28.42 \%$, kadar lemak $7.98 \%$, cemaran mikroba $2.1 \times 10^{2} \mathrm{koloni} / \mathrm{g}$, dan organoleptik 9.95. Mutu abon cakalang pada kemasan paper kraft adalah kadar air $5.83 \%$, kadar abu $8.39 \%$, kadar protein $27.84 \%$, kadar lemak $7.98 \%$, cemaran mikroba $3.7 \times 10^{2} \mathrm{koloni} / \mathrm{g}$, dan organoleptik 9. Hasil parameter mutu didapatkan produk terpilih dari kedua jenis kemasan adalah abon cakalang dengan kemasan alumunium karena memiliki mutu yang lebih tinggi, sehingga penentuan umur simpan dilanjutkan pada produk kemasan alumunium. Dari ketiga parameter yang diteliti diketahui bahwa kadar air menghasilkan energi aktivasi terendah $(2275,95 \mathrm{kal} / \mathrm{mol})$. Reaksi penurunan mutu produk abon ikan cakalang mengikuti ordo reaksi 1 dengan persamaan regresi linier $y=-1146 x+0,6187$. Pada suhu $30^{\circ} \mathrm{C}$ produk mampu bertahan lebih lama 222 hari $/ 7,4$ bulan, sedangkan pada suhu $40^{\circ} \mathrm{C} 196$ hari/ 6,5 bulan dan suhu $50^{\circ} \mathrm{C}$ selama 175 hari/5,8 bulan. Penggunaan Kemasan alumunium foil direkomendasikan untuk produk abon ikan cakalang dan disimpan disuhu $30^{\circ} \mathrm{C}$ atau suhu ruang dalam rangka memperpanjang umur simpan produk.
\end{abstract}

Kata kunci: Ikan cakalang, abon, ASLT, umur simpan.

\section{ABSTRACT}

The Pangandaran coast of West Java is one of the producers of shredded skipjack tuna products due to the high potential for skipjack tuna catches. One of the producers of shredded skipjack tuna in Pangandaran is the MSME Maha Karya. This study aims to determine the characteristics of the quality, nutritional value, and durability of the product using the ASLT method. Determination of the shelf life of shredded using two treatments of aluminum foil and kraft paper packaging with three temperature parameters $\left(30^{\circ} \mathrm{C}, 40^{\circ} \mathrm{C}\right.$, and $\left.50^{\circ} \mathrm{C}\right)$. The quality of skipjack tuna in aluminum packaging has the characteristics of having a water content of $5.42 \%$, ash content of $5.93 \%$, protein content of $28.42 \%$, fat content of $7.98 \%$, microbial contamination $2.1 \times 102$ colonies $/ g$, and organoleptic 9.95 . The quality of skipjack tuna in kraft paper packaging is water content $5.83 \%$, ash content $8.39 \%$, protein content $27.84 \%$, fat content $7.98 \%$, microbial contamination $3.7 \times 102$ colonies $/ g$, and organoleptic 9 . The results of quality parameters obtained selected products from both types of packaging is shredded skipjack tuna with aluminum packaging because it has a higher quality, so that the determination of shelf life is continued for aluminum packaged products. From the three parameters studied, it is known that the water content produces the lowest activation energy $(2275.95 \mathrm{cal} / \mathrm{mol})$. The reaction to the degradation of the quality of the skipjack tuna products followed the order of reaction 1 with the linear regression equation $y=-1146 x+0.6187$. At a temperature of $30^{\circ} \mathrm{C}$ the product was able to last longer for 222 days/7.4 months, while at a temperature of $40^{\circ} \mathrm{C} 196$ days $/ 6.5$ months and a temperature of $50^{\circ} \mathrm{C}$ for 175 days $/ 5.8$ months. The use of aluminum foil packaging is 
Buletin JSJ, 3 (2), 2021, 71-81

Available online di: http://ejournal-balitbang.kkp.go.id/index.php/JSJ/index

recommended for shredded skipjack tuna and stored at $30^{\circ} \mathrm{C}$ or room temperature in order to extend the shelf life of the product.

Keywords: Skipjack Tuna, shredded, ASLT, shelf life

\section{PENDAHULUAN}

Sumber daya kelautan dan perikanan merupakan salah satu potensi sumber daya alam yang sangat besar dan mendapatkan perhatian yang serius di Indonesia. Laut dan nelayan tidak dapat dipisahkan dari laut Indonesia, banyak masyarakat Indonesia khususnya di daerah perairan Pangandaran, pesisir perairan Pangandaran menjadikan ikan sebagai sumber penghasilan hidup mereka (Ismail \& Putra, 2017). Nilai produksi perikanan tangkap di Kabupaten Pangandaran pada bulan Januari tahun 2021 yaitu sebesar $45.460 .10 \mathrm{~kg}$ dengan jumlah rata-rata penghasilan sebanyak $R p$ 2.009.042.704. Salah satunya penangkapan ikan cakalang pada bulan Januari tahun 2021 sebanyak $350.70 \mathrm{~kg}$ dengan jumlah penghasilan rata-rata Rp 18.325 .51 (Dinas Perdagangan dan Koperasi UMKM Kabupaten Pangandaran, 2021).

Kabupaten Pangandaran memiliki banyak produk unggulan khususnya dibidang pengolahan perikanan. Komoditas tersebut tentunya melibatkan begitu banyak pelaku usaha mikro kecil dan menengah yang tersebar merata di seluruh wilayah Kabupaten Pangandaran yang diharapkan mampu bersaing dalam memproduksi, meningkatkan mutu produk, mengembangkan disain produk serta menciptakan berbagai inovasi sehingga produk UMKM yang berkualitas dapat dipasarkan dan mampu bersaing secara global. Jumlah UMKM di Kabupaten Pangandaran sebanyak 10.171 (Iriyanto, 2019). Salah satunya UMKM produk abon ikan cakalang, abon ikan cakalang merupakan salah satu usaha pengolahan hasil perikanan yang diversifikasi. Abon ikan cakalang mempunyai daya awet yang relatif lama dibandingkan dengan pengolahan tradisional perikanan lainnya. Abon cakalang merupakan daging ikan yang dicincang dan dikeringkan dengan penambahan bumbu-bumbu tertentu (Purwaningsih, 2015)

Selama penyimpanan, abon ikan akan tetap mengalami penurunan mutu akibat perubahan kimia dan fisika yang terjadi pada abon selama penyimpanan. Selama penyimpanan, produk pangan yang mengandung lemak atau minyak biasanya akan mengalami proses ketengikan selama proses penyimpanan (Polutu et all., 2015). Selama proses penyimpanan, abon akan tejadi kerusakan yang menyebabkan penurunan mutu sehingga mempengaruhi umur simpan abon cakalang. Oleh karena itu perlu dilakukan kajian untuk mengetahui tingkat ketahanan produk selama masa penyimpanan yang dipengaruhi oleh berbagai suhu penyimpanan (Karo et all., 2017).

Penggorengan pada suhu tinggi pada proses pembuatan abon yang dapat mempercepat terjadinya oksidasi pada abon. Reaksi oksidasi terjadi akibat serangan oksigen terhadap asam lemak tidak jenuh yang terkandung dalam minyak atau lemak. Reaksi oksidasi ini penyebab munculnya bau tidak enak (ketengikan) pada abon selama penyimpanan. Oleh karena itu diperlukan usaha untuk meningkatkan daya simpan hasil perikanan melalui proses pengawetan maupun pengolahan yang juga bertujuan untuk penganekaragaman produk olahan sehingga pemanfaatan ikan sebagai sumber protein lebih maksimal (Nurcholis, 2011).

Abon cakalang sangat baik dikonsumsi sebelum mengalami penurunan mutu atau sebelum masa kadaluwarsa agar tidak terjadi hal-hal yang tidak diinginkan. Pengemasan merupakan suatu cara untuk mencegah terjadinya kontasmiasi dari lingkungan luar produk. Pengemasan pada abon ikan sangat berpengaruh terhadap umur simpan dan mutu abon 


\section{Buletin JSJ, 3 (2), 2021, 71-81}

Available online di: http://ejournal-balitbang.kkp.go.id/index.php/JSJ/index

(Afdilla, et all., 2018). Dengan adanya pengemasan abon ikan dengan menggunakan cara pengemasan dan jenis pengemas tertentu diharapkan dapat memperpanjang daya simpan abon ikan dan dapat meningkatkan pemasaran (Nur, 2017)

Pengemasan disebut juga pembungkusan, pewadahan atau pengepakan, dan merupakan salah satu cara pengawetan bahan hasil produk perikanan, karena pengemasan dapat memperpanjang umur simpan bahan. Pengemasan adalah wadah atau pembungkus yang dapat membantu mencegah atau mengurangi terjadinya kerusakan- kerusakan pada bahan yang dikemas/dibungkusnya (Kencana, 2016). Selain untuk mewadahi/membungkus pangan, kemasan pangan juga mempunyai berbagai fungsi lain, diantaranya untuk menjaga pangan tetap bersih serta mencegah terjadinya kontaminasi mikroorganisme, menjaga produk dari kerusakan fisik, menjaga produk dari kerusakan kimiawi (misalnya permeasi gas, kelembaban/uap air), mempermudah pengangkutan dan distrisbusi, mempermudah penyimpanan, memberikan informasi mengenai produk pangan dan instruksi lain pada label, menyeragamkan volume atau berat produk dan membuat tampilan produk lebih menarik sekaligus menjadi media promosi (Direktorat Pengawasan Produk dan Bahan Berbahaya Badan Pengawas Obat dan Makanan RI. Materi Talkshow di RRI tentang Kemasan Pangan., 2008)

\section{METODE PENELITIAN}

Penelitian dilaksanakan di UMKM Maha Karya, Kabupaten Pangandaran untuk pengamatan alur proses, sementara untuk pengujian kimia dan mikrobiologi dilakukan di Laboratorium Politeknik Ahli Usaha Perikanan.

\section{Bahan dan Alat}

Bahan yang digunakan dalam penelitian ini adalah bahan pembantu dan bahan kimia untuk analisis. Bahan baku yang digunakan adalah abon cakalang dengan berat $75 \mathrm{gr} / \mathrm{Pcs}$ merek (Maha Karya) yang diproduksi UMKM Maha Karya Kab. Pangandaran. Kemasan abon menggunakan stand up pouch kombinasi Alumuniumfoil dan plastic jenis polethylene terepthalate (PET/PETE). Serta alumunium foil dengan ketebalan $0.10 \mathrm{~mm}$ dan Paper kraft dengan ketebalan $0.13 \mathrm{~mm}$.

Bahan untuk analisis kimia adalah pelarut aquades, $\mathrm{HCL}$ pekat, $\mathrm{NaOH} 0,1$, kertas saring, reagen TBA (0.02 M.Thiobarbituric-acid dalam 90\% asam asetat glasial), PCA (Plate Count Agar) Himedia dengan bobot $23,5 \mathrm{gr} / 1000 \mathrm{ml}$, campuran katalis protein mengandung $\mathrm{K}_{2} \mathrm{SO} 4$ dan $\mathrm{CuSO}_{4}$ (3:1), kertas timbang bebas $\mathrm{N}$ (whatman 541), $\mathrm{NaOH} 40 \%, \mathrm{H} 3 \mathrm{BO} 3$, Indikator Metil Red (MM), Indikator Blue Cresol Green (BCG), Indikator campuran bromocresol green $0,1 \%$ dan metil red $0,1 \%$, larutan boraks $0,1 \mathrm{~N}, \mathrm{~N}-\mathrm{Heksana}, 4 \mathrm{~N} \mathrm{HCl}$, Alkohol $70 \%$.

Alat yang digunakan adalah alat destruksi (Digestor, 2006) dan destilasi Kjeldahl(Kjeltec TM 2100), labu tabung protein, buret $50 \mathrm{ml}$, labu ukur $100 \mathrm{ml}$, neraca digital, gelas ukur $(10,25$, $100,500 \mathrm{ml}$ ), pipet gondok $10 \mathrm{ml}$ dan pipet tetes, beaker glass, corong, botol semprot, tissu, 1 set Soxtec System, oven, desikator, selubung lemak, lumpang, timbangan analitik, kepekaan 0,1 mg, cawan abu porselin, tungku pengabuan, gunting, blender atau alat penghancur, alat penjepit/ tang krusibel, desikator, sendok stainless steel, cawan porselin, timbangan analitik kepekaan $0,01 \mathrm{mg}$, cawan petri, tips, tabung reaksi, erlenmeyer $(250,300$, $500,1000 \mathrm{ml}$ ), tabung reaksi, plastik, spektrofotometer, hot plate, magnetik stirer, labu destilasi, kuvet kaca, baskom, stomatcher, waterbath, micrometer sekrup, aluminium foil, paper kraft, pipet tetes $1 \mathrm{ml}$, kertas cokelat berlapis lilin, kapas, karet, colony counter, dan spidol. 
Buletin JSJ, 3 (2), 2021, 71-81

Available online di: http://ejournal-balitbang.kkp.go.id/index.php/JSJ/index

\section{Prosedur Penelitian}

Prosedur pengumpulan data dilakukan dengan dua metode yaitu primer dan sekunder. Data primer merupakan data data yang diperoleh dari sumbernya, melalui pengambilan sampel dari UMKM Maha Karya Kabupaten Pangandaran, pengujian mikrobiologi, kimia dan sensori. Sedangkan data sekunder dapat diperoleh dari studiliterature beberapa jurnal umur simpan, dan tulisan yang berkaitan dengan judul yang diambil penulis untuk menunjang data primer agak lebih akurat dan konkrit. Dengan penentuan karakteristik penentu kerusakan dengan pencarian referensi terkait produk, penentuan lama waktu penyimpanan berdasarkan jenis produk, pengamaytan alur proses pembuatan abon ikan cakalang di UMKM Maha Karya, pengujian pada parameter kerusakan produk, menganalisis data dan penentuan umur simpan produk.

Rincian prosedur penelitian sebagai berikut (Gambar 1):

1) Pengamatan alur proses pengolahan abon cakalang di UMKM Maha Karya dan Pengujian terhadap mutu bahan baku ikan segar dilakukan oleh 6 panelis dengan 3 kali pengamatan dan 1 kali pengulangan, untuk bahan baku ikan segar dengan menggunakan score sheet (lembar penilaian). Pengujian pada ikan segar ada 6 parameter sesuai dengan SNI 2729-2013 yaitu Kenampakan (Mata, Insang, Lendir), daging, bau dan tekstur;

2) Penentuan perlakuan kemasan dengan dua kemasan (alumunium foil dan paper kraft);

3) Pengujian karakteristik mutu produk dengan 2 jenis kemasan (ALT, Protein, Lemak, Kadar Air, kadar Abu, Organoleptik dan TBA);

4) Pendugaan umur simpan pada abon ikan cakalang dilakukan dengan metode percepatan Accelerated Shelf Life Testing (ASLT). Sampel abon dilakukan penyimpanan di dalam kemasan terpilih (penentuan kemasan dengan pengujian mutu produk) pada tiga suhu yang berbeda yaitu Suhu Ruang $\left(30^{\circ} \mathrm{C}\right), 40^{\circ} \mathrm{C}$ dan $50^{\circ} \mathrm{C}$. Setiap 10 hari sekali sampai dengan hari ke 70 dilakukan analisis pada parameter kritis produk meliputi kadar air, TBA, dan organoleptik.

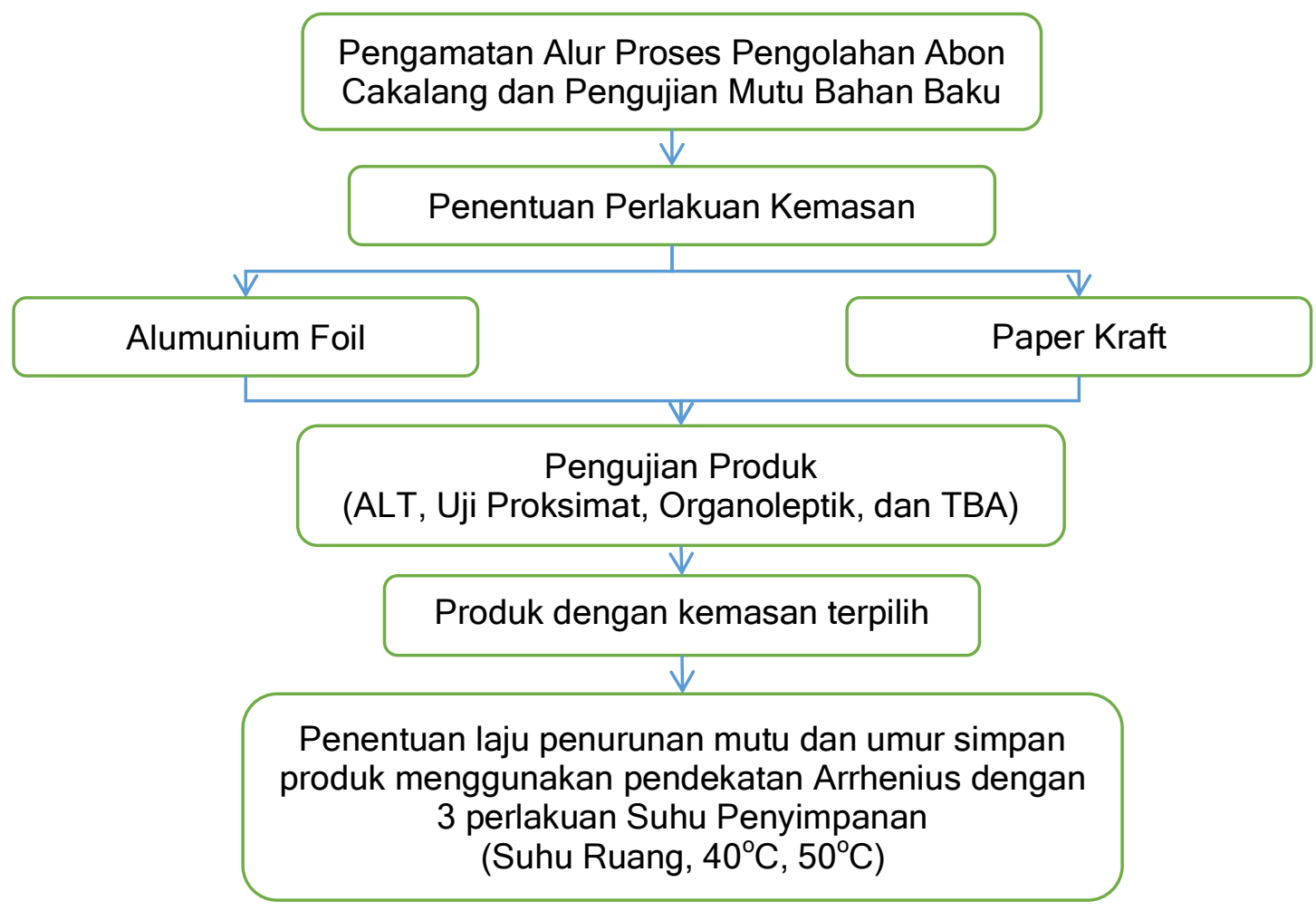

Gambar 1. Alur Prosedur Penelitian 


\section{Buletin JSJ, 3 (2), 2021, 71-81}

Available online di: http://ejournal-balitbang.kkp.go.id/index.php/JSJ/index

Umur simpan adalah periode waktu bagi produk secara sensorik dan nutrisi masih aman dan masih bisa dikonsumsi (Arif, 2018) Metode Accelerated Shelf-life Testing (ASLT) dengan model Arrhenius, yaitu dengan cara menyimpan produk pada suhu penyimpanan yang cepat rusak, baik pada kondisi suhu atau kelembapan pada ruang penyimpanan yang lebih tinggi (Herawati, 2012). Penelitian ini bertujuan untuk menentukan umur simpan (shelf life), abon cakalang dengan menggunakan kemasan paper kraft dan alumunium foil dengan menggunakan metode simulasi plotting atau untuk menentukan laju penurunan mutu.

Pengolahan data dilakukan dengan menggunkaan model matematika, yaitu model Arrhenius. Data dari analisis setiap parameter diplotkan terhadap waktu (hari) sehingga didapatkan persamaan regresi linearnya dan diperoleh tiga persamaaan untuk tiga kondisi suhu penyimpanan produk $\mathrm{y}=\mathrm{bx}+\mathrm{a}$. Dimana $\mathrm{y}=$ nilai karakteristik produk, $\mathrm{x}=$ waktu penyimpanan (hari), $b=l a j u$ perubahan karakteristik (slope=laju penurunan mutu=k), dan $\mathrm{a}=$ nilai karakteristik awal produk. Pemilihan orde reaksi untuk suatu parameter dilakukan dengan cara membandingkan koefisien determinasi (R2) tiap persamaan regresi linear pada suhu yang sama. Orde reaksi dengan nilai R2 yang lebih besar merupakan orde reaksi yang digunakan pada parameter uji tersebut.

Nilai In $\mathrm{k}$ dan $1 / \mathrm{T}(1 / \mathrm{K})$ yang merupakan parameter Arrhenius ditabulasikan, selanjutnya nilai In $\mathrm{k}$ diplotkan terhadap $1 / \mathrm{T}(1 / \mathrm{K})$ dan didapatkan nilai intersep dan slope dari persamaan regresi linier In $\mathrm{k}=\mathrm{In} \mathrm{k} 0-(\mathrm{Ea} / \mathrm{R})(1 / \mathrm{T})$ dimana In $\mathrm{k} 0=$ intersep, $\mathrm{Ea} / \mathrm{R}=$ =slope, Ea=energi aktivasi, dan $\mathrm{R}=\mathrm{konstanta}$ gas ideal $(1.986 \mathrm{kal} / \mathrm{mol})$. Dari persamaan tersebut diperoleh nilai konstanta $\mathrm{k} 0$ yang merupakan faktor eksponensial dan nilai energi aktivasi (Ea) reaksi perubahan karakteristik produk kemudian ditentukan model persamaan laju reaksi $(k)$ perubahan karakteristik produk siap pakai dengan $\mathrm{k}=\mathrm{k} 0 . \mathrm{e}-\mathrm{E} / \mathrm{RT}$.

Penentuan parameter kunci dengan melihat parameter yang mempunyai energi aktivasi terendah. Umur simpan saus buah merah pedas dihitung dengan persamaan kinetika reaksi berdasarkan orde reaksinya, yaitu sebagai berikut:
$t=(A 0-A t) / k$
(Pers. Orde Nol)
$t=\ln (A 0-A t) / k$
(Pers. Orde Satu)

Keterangan : $t=$ umur simpan produk (hari), $A 0=$ nilai atribut mutu di awal (hari ke-0), $A t=$ nilai atribut mutu di akhir (hari ke-t), dan $k=$ konstanta penurunan mutu.

\section{HASIL DAN PEMBAHASAN}

\section{Alur Proses}

Abon ikan cakalang UMKM Maha Karya menggunakan bahan baku ikan segar dari hasil penangkapan ikan di perairan pantai Pangandaran, sehingga kualitas ikan cakalang bermutu baik. Cakalang banyak digemari karena tekstur dagingnya yang baik dengan cita rasa yang tinggi (Yanglera et all., 2017). Penanganan dan pengolahan abon cakalang di UMKM Maha Karya memilikitahapan proses sesuai dengan SNI7690.3:2013.

Alur proses pengolahan abon ikan dimulai dengan penerimaan bahan baku. Bahan baku yang baru datang bisa langsung diproses dan apabila tidak memungkinkan untuk diproses semua, bahan baku disimpan terlebih dahulu didalam freezer dengan suhu antara -180C sampai -250C dan bisa diproses keesokan harinya (Jasila \& Fadilatun, 2014). Bahan baku ikan cakalang segar yang akan digunakan dipilih langsung oleh pemilik UMKM Maha Karya, tujuannya agar mendapatkan bahan baku dan bahan lainnya sesuai spesifikasi mutu dan keamanan hasil perikanan. Bahan baku dan bahan lainnya diuji secara organoleptik dan ditangani secara cepat, cermat, saniter sesuai dengan prinsip teknik penanganan yang baik dan benar. 
Buletin JSJ, 3 (2), 2021, 71-81

Available online di: http://ejournal-balitbang.kkp.go.id/index.php/JSJ/index

Proses pencucian dilakukan bertujuan untuk menghilangkan kotoran yang menempel pada bahan baku, bekas darah ataupun lendir. Sebelum pencucian dilakukan semua peralatan harus dipersiapkan seperti wadah plastik besar, pisau jika dibutuhkan. Proses pencucian di UMKM Maha Karya menggunakan air bersih yang mengalir dan dilakukan langsung setelah bahan baku datang. Proses ini dilakukan oleh 2 orang karyawan. Kemudian dilakukan proses penyiangan, proses penyiangan adalah proses pembersihan kepala, insang, isi perut. Setelah bersih dilakukan pencucian II untuk menghilangkan sisa kotoran.

Proses selanjutnya adalah pengukusan. Pengukusan dilakukan kurang lebih selama 10-15 menit dengan air mendidih sekitar $100^{\circ} \mathrm{C}$. Secara umum tujuan pengukusan adalah untuk membuat tekstur bahan menjadiempuk. Kondisi bahan yang empuk mudah dicabik-cabik menjadi serat-serat yang halus. Ikan memiliki daging yang cukup lunak sehingga lebih tepat dikukus dari padadirebus tinggi suhu tidak boleh berlebihan tetapi cukup sampai mencapai titik didih saja (Jasila \& Fadilatun, 2014). Setelah ikan dikukus dilakukan pemisahan daging dari duri dengan cara dicabik, kemudian daging cakalang di lakukan pengempresan untuk mengurangi kandungan air. Daging cakalang dicampuri bumbu dan dilakukan penggorengan. Abon yang sudah melalui proses penggorengan kemudian dimasukkan kedalam mesin spinner. Saringan didalam mesin berputar secara cepat dan otomatis sehingga minyak keluar dengan sendirinya melalui corong yang terdapat pada mesin spinner.

Abon ikan yang telah ditimbang kemudian dilakukan proses pengemasan menggunakan mesin sealer. Pengemasan bertujuan untuk memudahkan dalam proses distribusi, penyimpanan, penjualan serta melindungi atau mengurangi kerusakan dari bahaya cemaran dan gangguan fisik (gesekan, benturan dan getaran) (Sucipta et all., 2017). Proses terakhir adalah penyimpanan disuhu ruang. Kemasan Abon Ikan Cakalang dapat dilihat pada Gambar 2.

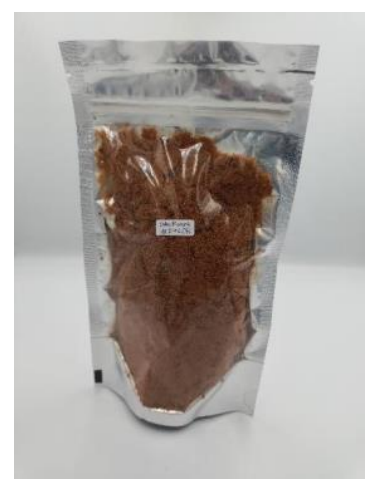

(a)

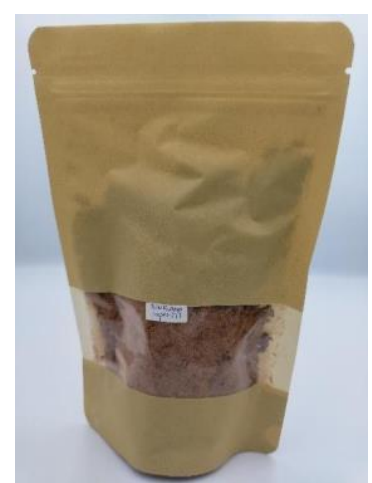

(b)

Gambar 2. Kemasan Abon Ikan Cakalang (a) Alumunium Foil dan (b) Paper Kraft

\section{Karakteristik Mutu Abon Cakalang}

Hasil pengamatan bahan baku ikan segar terdapat nilai hasil organoleptik yaitu 8 , dari hasil pengamatan ini sudah memenuhi SNI 2729:2013, sehingga bahan baku bisa melanjutkan proses produksi. Pengujian Mutu Abon Cakalang dilakukan pengujian kimia (kadar air, kadar abu, protein, lemak dan TBA), sedangkan untuk pengujian mikrobiologi dilakukan Angka Lempeng Total (ALT). Hasil pengujian mutu abon cakalang pada kemasan almunium foil dan paper dapat dilihat pada Tabel 1 
Buletin JSJ, 3 (2), 2021, 71-81

Available online di: http://ejournal-balitbang.kkp.go.id/index.php/JSJ/index

Tabel 1. Mutu Abon Ikan Cakalang Pada Kemasan Alumunium Foil dan Paper di UMKM Maha Karya

\begin{tabular}{clccc}
\hline \multirow{2}{*}{ No } & \multicolumn{1}{c}{ Kriteria Uji } & \multicolumn{2}{c}{ Hasil (\%) } & Persyaratan (\%) \\
\cline { 3 - 5 } & & Alumunium foil & Paper kraft & \\
\hline A. & Sensori & 9.95 & 9 & Min 7 \\
B. & Kimia & & & \\
& 1. Kadarair & 5.42 & 5.83 & Maks 7 \\
& 2. Kadar abu & 5.93 & 8.39 & Maks 7 \\
& 3. Protein & 28.42 & 27.84 & Min 15 \\
& 4. Lemak & 7.98 & 7.98 & Maks 30 \\
C. & Cemaran Mikroba-ALT & $2.1 \times 10^{2} \mathrm{kol} / \mathrm{gr}$ & $3.7 \times 10^{2} \mathrm{kol} / \mathrm{gr}$ & Maks. $5 \times 10^{4}$ \\
\hline
\end{tabular}

Dari hasil pengujian mutu produk maka didapatkan penggunaan kemasan alumunium foil lebih baik daripada menggunakan kemasan paper, sehingga produk kemasan alumunium foil menjadi produk terpilih dalam menentukan umur simpan. Ikan merupakan sumber energi yang sangat diperlukan bagi tubuh manusia untuk menunjang kegiatan sehari-hari akan tetapi kekurangan protein pada ikan juga dapat menimbulkan kesehatan yang buruk dan dapat meningkatkan resiko penyakit infeksi, penyakit kardiovaskular, diabetes, serta kanker yang merupakan penyebab utama kematian di Indonesia (Argo et all., 2012). Untuk menentukan nilai mutu akhir abon cakalang, dilakukan penyimpanan pada suhu yang tinggi daripada suhu penyimpanan normalnya. Penyimpanan dilakukan disuhu $30^{\circ} \mathrm{C}, 40{ }^{\circ} \mathrm{C}$, dan $50{ }^{\circ} \mathrm{C}$ diamati secara berkala setiap 10 hari sekali oleh 6 panelis tidak terlatih sampai panelis menolak abon cakalang. Uji penerimaan dilakukan dengan parameter pengujian karakteristik rasa, warna, penampakan dan aroma.

UMKM Maha Karya menjual abon ikan cakalang dengan berat perkemasan yaitu $100 \mathrm{~g}$. Mengacu pada Peraturan Kepala Badan Pengawas Obat dan Makanan Nomor 16 tahun 2019 tentang pencantuman informasi nilai gizi untuk pangan olahan yang diproduksi oleh usaha mikro dan usaha kecil, bahwa takaran saji untuk jenis pangan olahan abon ikan cakalang adalah $10 \mathrm{~g}-25 \mathrm{gr}$ dan untuk jumlah kebutuhan zat gizi dalam sehari mengacu pada nilai Angka Kecukupan Gizi (AKG). Nilai Kecukupan Gizi Abok Ikan Cakalang Kemasan Alumunium dapat dilihat pada Tabel 2.

Tabel 2. Nilai Kecukupan Gizi Abon Cakalang Kemasan Alumunium

\begin{tabular}{lcc}
\hline & Informasi Nilai Gizi \\
\hline $\begin{array}{l}\text { Takaran Saji } \\
\text { Jumlah Saji Perkemasan }\end{array}$ & \multicolumn{2}{c}{25 gram } \\
\hline Energi Total & 4 \\
\hline Energi dari Lemak & $30 \mathrm{kkal}$ \\
\hline & & $\% \mathrm{AKG}$ \\
Lemak Total & $2 \mathrm{~g}$ & $3 \%$ \\
Protein & $7 \mathrm{~g}$ & $12 \%$ \\
Karbohidrat & $13 \mathrm{~g}$ & $4 \%$ \\
\hline *Persen AKG berdasarkan kebutuhan energy 2150 kkal. Kebutuhan energiAnda \\
\multicolumn{2}{c}{ mungkin lebih tinggi atau lebih rendah. } \\
\hline
\end{tabular}

\section{Kinetika Reaksi Dasar Untuk Menduga Penurunan Umur}

Hasil analisa perubahan dari kadar air, TBA dan organoleptik pada abon cakalang kemasan alumunium foil yang disimpan pada tiga kondisi suhu penyimpanan dapat dilihat pada Tabel 3. 
Buletin JSJ, 3 (2), 2021, 71-81

Available online di: http://ejournal-balitbang.kkp.go.id/index.php/JSJ/index

Tabel 3 Nilai perubahan kadar air (\%) abon ikan cakalang pada kemasan alumunium foil

\begin{tabular}{cccccccccc}
\hline \multirow{2}{*}{ Parameter } & \multirow{2}{*}{ Suhu } & \multicolumn{8}{c}{ Waktu (Hari) } \\
\cline { 3 - 9 } & & 0 & 10 & 20 & 30 & 40 & 50 & 60 & 70 \\
\hline \multirow{3}{*}{ Kadar Air (\%) } & Ruang & 5.6325 & 5.7883 & 6.2704 & 6.5206 & 7.0513 & 7.3904 & 8.2187 & 8.4318 \\
& $40^{\circ} \mathrm{C}$ & 5.6325 & 5.8682 & 6.4142 & 6.7124 & 7.1104 & 7.7577 & 8.5302 & 8.7833 \\
& $50^{\circ} \mathrm{C}$ & 5.6352 & 6.1319 & 6.7253 & 7.1548 & 8.1452 & 8.5194 & 8.9065 & 9.1765 \\
\hline TBA & Ruang & 0.18 & 0.18 & 0.19 & 0.53 & 0.69 & 0.76 & 1.07 & 1.44 \\
(malonaldehid & $40^{\circ} \mathrm{C}$ & 0.18 & 0.24 & 0.28 & 0.55 & 0.83 & 0.97 & 1.12 & 1.76 \\
a/kg sampel) & $50^{\circ} \mathrm{C}$ & 0.18 & 0.70 & 0.94 & 1.07 & 1.29 & 1.81 & 2.06 & $\underline{2.45}$ \\
\hline \multirow{3}{*}{ Organoleptik } & Ruang & 8.95 & 8.95 & 8.83 & 8.70 & 8.60 & 8.48 & 8.35 & 8.15 \\
& $40^{\circ} \mathrm{C}$ & 8.95 & 8.78 & 8.60 & 8.43 & 8.23 & 8.13 & 8.00 & 7.88 \\
& $50^{\circ} \mathrm{C}$ & 8.95 & 8.73 & 8.55 & 8.23 & 7.83 & 7.40 & 7.08 & 6.50 \\
\hline
\end{tabular}

Dari hasil Tabel 3 didapatkan perubahan nilai parameter dari hari-0 sampai hari-70. Dari hasil tersebut dilakukan perhitungan umur simpan dengan menggunaan persamaan Arrhenius. Persamaan Arrhenius didapatkan dengan terlebih dulu mencari nilai $x$ dan y pada masing-masing suhu. Laju Perubahan Kadar Air, TBA, dan Organoleptik dapat dilihat pada Gambar 3.

Dari regresi linier yang didapat dibuatkan persamaan Arrhenius dan dihitung energi aktivasi kerusakan pada setiap parameter. Persamaan Arrhenius dari setiap parameter dapat dilihat pada Gambar 4. Hasil perhitungan nilai energi aktivasi tiap parameter adalah 2275,95 $\mathrm{Kal} / \mathrm{mol}^{\circ} \mathrm{K}$ untuk parameter kadar air, $5442,03 \mathrm{Kal} / \mathrm{mol}^{\circ} \mathrm{K}$ untuk parameter TBA, dan 9224,70 $\mathrm{Kal} / \mathrm{mol}^{\circ} \mathrm{K}$ untuk parameter organoleptik.

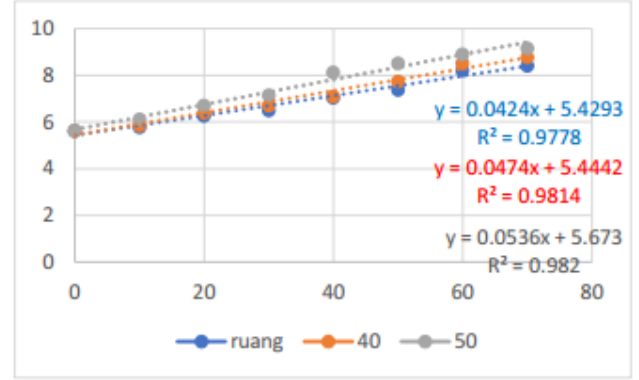

Ordo 0

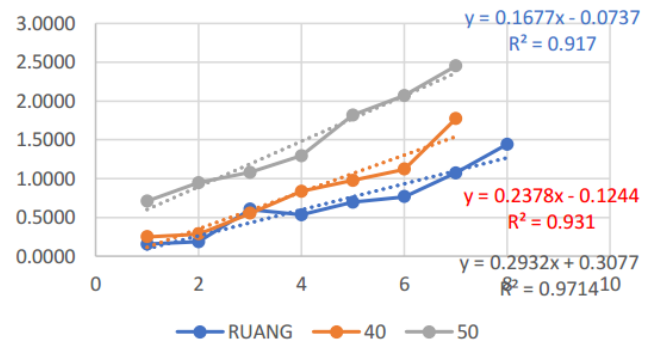

Ordo 0

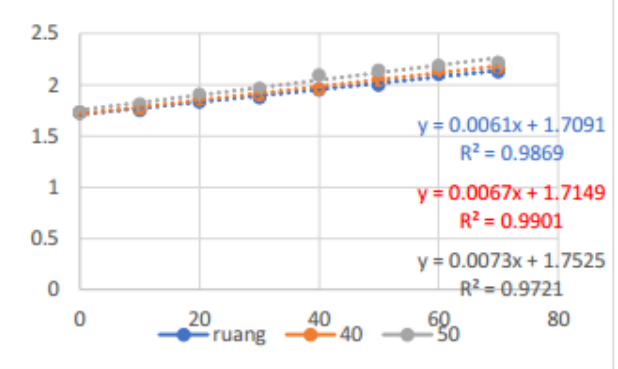

Ordo 1

(a)

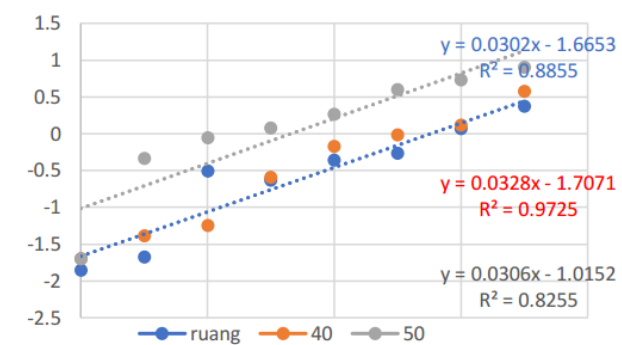

Ordo 1

(b) 
Buletin JSJ, 3 (2), 2021, 71-81

Available online di: http://ejournal-balitbang.kkp.go.id/index.php/JSJ/index

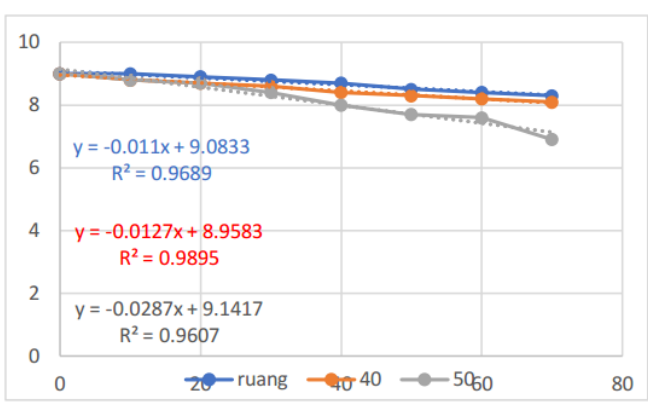

Ordo 0

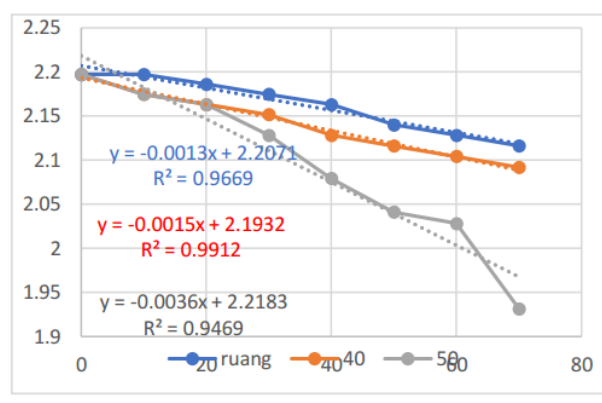

Ordo 1

(c)

Gambar 3. Laju Perubahan (a) Kadar Air (b) TBA (c) Organoleptik

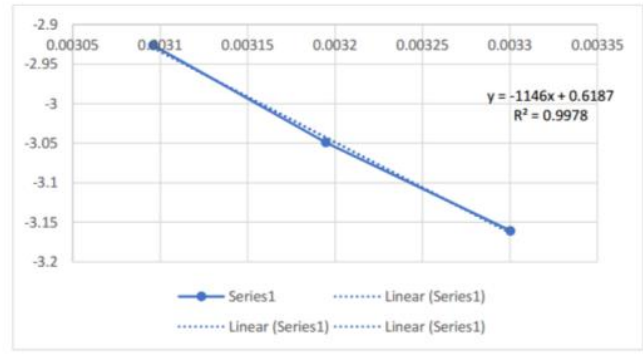

(a)

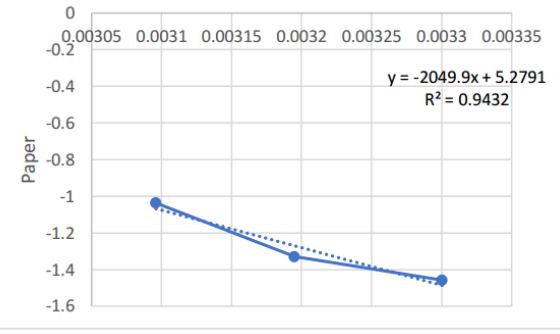

(b)

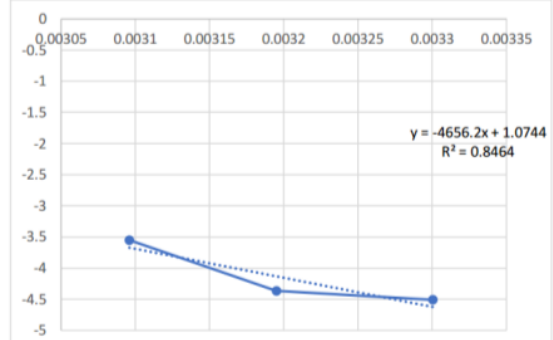

(c)

Gambar 4. Persamaan Arrhenius Parameter (a) Kadar Air (b) TBA (c) Organoleptik

\section{Penentuan Umur Simpan}

Pendugaan umur simpan abon ikan cakalang dilakukan perhitungan dengan menggunakan persamaan regresi linear dari parameter yang memiliki nilai Energi aktivasi terendah. Dari masing-masing persamaan diperoleh nilai $k$ yang dapat digunakan untuk menghitung umur simpan produk. Nilai $k$ tersebut diperoleh dari rumus In $k=$ In $k 0-E a / R(1 / T)$, dimana In $\mathrm{k} 0=$ intersep, $\mathrm{Ea} / \mathrm{R}=$ slope. Nilai $\mathrm{k}$ yang diperoleh kemudian dimasukkan dalam persamaan kinetika reaksi berdasarkan ordo reaksinya (Khamidah, 2010). Parameter uji pada pendugaan umur simpan mengikuti kinetika reaksi ordo nol dikarenakan nilai R2 lebih tinggi jika dibandingkan dengan nilai R2 ordo satu. Persamaan yang diperoleh untuk menduga umur simpan abon ikan cakalang yaitu In $\mathrm{k}=-1146(1 / \mathrm{T})+0,6187$ dengan energi aktivasi perubahan kadar air sebesar 2275,95 kal/mol K (Tabel 4). Parameter kritis penentuan umur simpan produk abon ikan cakalang adalah kadar air yang memiliki energi aktivasi terendah jika dibandingkan dengan parameter lain yang dianalisis. Tabel 5 diperoleh umur simpan saus buah merah pedas perlakuan suhu penyimpanan yang berbeda. 
Buletin JSJ, 3 (2), 2021, 71-81

Available online di: http://ejournal-balitbang.kkp.go.id/index.php/JSJ/index

Tabel 4. Persamaan Arrhenius dan Energi Aktivasi Setiap Parameter Uji Abon Ikan Cakalang

\begin{tabular}{lcc}
\hline \multicolumn{1}{c}{ Parameter } & Persamaan Arrhenius & Energi Aktivasi $(\mathrm{Kal} / \mathrm{mol})$ \\
\hline Kadar Air & $\ln \mathrm{k}=-1146(1 / \mathrm{T})+0,6187$ & 2275,95 \\
TBA & $\ln \mathrm{k}=-2049,9(1 / \mathrm{T})+5,2791$ & 5442,03 \\
Organoleptik & In $\mathrm{k}=-4656,2(1 / \mathrm{T})+1,0744$ & 9224,70 \\
\hline
\end{tabular}

Tabel 5. Hasil perhitungan penentuan umur simpan abon ikan cakalang dengan parameter air

\begin{tabular}{ccc}
\hline Jenis Kemasan & \multicolumn{2}{c}{ Alumunium Foil } \\
\cline { 2 - 3 } Waktu & Hari & Bulan \\
\hline Suhu Ruang $\left(30^{\circ} \mathrm{C}\right)$ & 222 & 7.4 \\
$40^{\circ} \mathrm{C}$ & 196 & 6.5 \\
$50^{\circ} \mathrm{C}$ & 175 & 5.8 \\
\hline
\end{tabular}

Dari Tabel 4 dapat dilihat bahwa kenaikan suhu dapat menyebabkan terjadinya kecepatan reaksi yang lebih besar dimana hal tersebut ditunjukkan oleh kemiringan garis yang semakin tajam dan harga konstanta penurunan mutu yang semakin besar. Jika kecepatan reaksi besar maka konsentrasi reaktan dan hasil reaksi akan semakin besar pula sehingga produk menjadi semakin cepat rusak. Jika produk cepat rusak, maka semakin pendek umur simpannya (Haryati et al, 2015). Semakin tinggi suhu penyimpanan maka produk akan lebih cepat mengalami kerusakan. Seperti yang tertera pada Tabel 5 pada suhu $30^{\circ} \mathrm{C}$ produk mampu bertahan lebih lama 222 hari/7,4 bulan, sedangkan pada suhu $40^{\circ} \mathrm{C} 196$ hari/6,5 bulan dan suhu $50^{\circ} \mathrm{C}$ selama 175 hari $/ 5,8$ bulan.

\section{KESIMPULAN}

Alur proses pengolahan abon cakalang di UMK Maha Karya sesuai dengan SNI SNI7690.3:2013 yaitu penerimaan bahan baku, pencucian I, penyiangan, pencucian II, pengukusan, pencabikan, pengepresan, pencampuran, pemasakan, penirisan minyak, pengemasan, penyimpanan. Mutu abon ikan cakalang pada kemasan alumunium mempunyai karakteristik dengan memiliki kadar air 5.42\%, kadar abu 5.93\%, kadar protein $28.42 \%$, kadar lemak $8.23 \%$, cemaran mikroba $2.1 \times 10^{2}$ koloni/g, dan organoleptik 9.95 . Sedangkan Mutu abon ikan cakalang pada kemasan paper kraft mempunyai karakteristik dengan memiliki kadar air 5.83\%, kadar abu $8.39 \%$, kadar protein $27.84 \%$, kadar lemak $7.98 \%$, cemaran mikroba $3.7 \times 10^{2}$ koloni/g, dan organoleptik 9 .

Berdasarkan hasil uji pendugaan umur simpan diketahui bahwa semakin tinggi suhu penyimpanan abon ikan cakalang maka umur simpan produk abon ikan cakalang semakin menurun. Dari ketiga parameter yang diteliti diketahui bahwa kadar air menghasilkan energi aktivasi terendah $(2275,95 \mathrm{kal} / \mathrm{mol})$. Energi aktivasi terendah digunakan untuk menentukan umur simpan produk abon ikan cakalang. Reaksi penurunan mutu produk abon ikan cakalang mengikuti ordo reaksi 1 dengan persamaan regresi linier $y=-1146 x+0,6187$. Pada suhu $30^{\circ} \mathrm{C}$ produk mampu bertahan lebih lama 222 hari/7,4 bulan, sedangkan pada suhu $40^{\circ} \mathrm{C} 196$ hari/ 6,5 bulan dan suhu $50^{\circ} \mathrm{C}$ selama 175 hari $/ 5,8$ bulan. Penggunaan Kemasan alumunium foil direkomendasikan untuk produk abon ikan cakalang dan disimpan disuhu $30^{\circ} \mathrm{C}$ atau suhu ruang dalam rangka memperpanjang umur simpan produk.

\section{DAFTAR PUSTAKA}

Afdillah, W., Sulaiman, I., \& Martunis. (2018). Pengaruh Kemasan Aluminium Foil dan Botol Kaca terhadap Umur Simpan Abon Ikan Tongkol (Euthynnus affinis) dengan 


\section{Buletin JSJ, 3 (2), 2021, 71-81}

Available online di: http://ejournal-balitbang.kkp.go.id/index.php/JSJ/index

Pendekatan Metode Arrhenius.

Argo, D. B., Sugiarto, Y., \& Irianto, B. A. (2012). Analisis Kandungan Abon Ikan Patin (Pangasius pangasius) dengan Treatment Alat "Spinner Pulling Oil" sebagai Pengentas Minyak Otomatis.

Arif A. B. (2018). Metode Accelarated Shelf Life Test (ASLT) Dengan Pendekatan Arrhenius Dalam Pendugaan Umur Simpan Sari Buah Nanas, Pepaya Dan Cempedak. Informatika Pertanian, 25(2), 189.

Badan Standardisasi Nasional. (1995). Abon, No. SNI 01-3707-1995 (Jakarta). BSN. aksessni.bsn.go.id

Badan Standardisasi Nasional. (2013). Abon Ikan-Bagian 1: Spesifikasi, No. SNI 7690.1:2013 (Jakarta). BSN. akses-sni.bsn.go.id.

Dinas Perdagangan dan Koperasi UMKM Kabupaten Pangandaran. (2021). Nilai Produksi Perikanan Tangkap Kabupaten Tangerang.

Direktorat Pengawasan Produk dan Bahan Berbahaya Badan Pengawas Obat dan Makanan RI. Materi Talkshow di RRI tentang Kemasan Pangan. (2008). PLASTIK SEBAGAI KEMASAN PANGAN.

Herawati, H. (2012). Penentuan Umur Simpan Pada Produk Pangan.

Haryati, E. Teti, H. Feronika, dan Ahmadi. (2015). Pendugaan Umur Simpan Menggunakan Metode Accelerated Ahelf Life Testing (ASLT) dengan Pendekatan Arrhenius pada Produk Tape Ketan Hitam Khas Mojokerto Hasil Sterilisasi. Jurnal Pangan dan Agroindustri. Vol. 1 (3): 156-165.

Iriyanto, B. (2019). Badan Pusat Statistik Pendataan dan Penyusunan Data UMKM.

Ismail, A. M., \& Putra, E. D. (2017). Inovasi Pembuatan Abon Ikan Cakalang Dengan Penambahan Jantung Pisang. XIX.

Jasila, I., \& Fadilatun, Z. (2014). Pembuatan Abon Ikan Patin (Pangasius hypophthalmus) di Pradipta Jaya Food Probolinggo.

Khamidah, A. (2010). Aplikasi Metode ASLT dalam Produk Pangan. Balai Pengkajian Teknologi Pertanian Jawa Timur. Malang.

Karo, C. Y., Noptianti, R., \& Lestari, D. S. (2017). Pengaruh Variasi Suhu TerhadapMutu Abon Ikan Ekonomis Rendah Selama Penyimpanan.

Kepala Badan Pengawas Obat dan Makanan. (2019). Peraturan Badan Pengawas Obatdan Makanan Nomor 22 Tahun 2019 tentang Informasi Nilai Gizi pada Label Pangan Olahan (Jakarta). BPOM.

Kencana, D. K. P. (2016). Pengemasan Pangan.

Nurcholis, M. (2011). Praktikum Analisa Pangan.

Polutu, A. K., Sulistijowati, R., \& Dali, A. F. (2015). Pengaruh Jenis Kemasan dan Lama Penyimpanan pada Suhu Ruang terhadap Nilai TBA Abon Ikan Sidat.

Purwaningsih, S. (2015). Studi Pembuatan Abon Ikan Cakalang (Katsuwonus palamis).

Sucipta, I. N., Suriasih, K., \& Kencana, P. K. D. (2017). Pengemasan Pangan, Kajian Pengemasan yang Aman, Nyaman, efektif dan Efisien (1 ed.). Udayana University Press.

Yanglera, A., Nur, I. A., \& Mustafa, A. (2017). Studi beberapa karakteristik biologi Ikan Cakalang (Katsuwonus pelamis) di Perairan Menui Kepulauan Kabupaten Morowali Sulawesi Tengah. 